\title{
Correction to: Innovation and improvement of visual communication design of mobile app based on social network interaction interface design
}

\author{
Haotian $\mathrm{Wu}^{1,2} \cdot$ Guangan $\mathrm{Li}^{1,3}$ \\ Published online: 14 January 2020 \\ C) Springer Science+Business Media, LLC, part of Springer Nature 2020
}

\section{Correction to: Multimedia Tools and Applications (2019) \\ https://doi.org/10.1007/s11042-019-7523-6}

The reference list contains errors. The correct references are given below.

[2] Kraft B, Nagl M (2007). Visual knowledge specification for conceptual design: definition and tool support[J]. Advanced Engineering Informatics 21(1): 67-83. https://doi.org/10.1016 /j.aei.2006.10.001

[4] Lim C, Mostafa N, Park J (2017). Digital Omotenashi: toward a smart tourism design systems[J]. Sustainability 9(12): 2175. https://doi.org/10.3390/su9122175

[19] Sailer M, Hense J U, Mayr S K, et al. (2017). How gamification motivates: an experimental study of the effects of specific game design elements on psychological need satisfaction[J]. Computers in Human Behavior 69: 371-380. https://doi.org/10.1016/j. chb.2016.12.033

The online version of the original article can be found at https://doi.org/10.1007/s11042-019-7523-6

Haotian $\mathrm{Wu}$

wuhaotian784@gmail.com

Guangan Li

Hnasmy@126.com

1 Shanghai University of Engineering Science, Shanghai, China

2 Edinburgh Napier University, Edinburgh, UK

3 Shanghai International Institute of Design and Innovation, Tongji University, Shanghai, China 
[20] Walia N, Srite M, Huddleston W (2016). Eyeing the web interface: the influence of price, product, and personal involvement[J]. Electronic Commerce Research 16(3): 297-333. https://doi.org/10.1007/s10660-015-9200-9

[26] Hussain J, U1 Hassan A, Muhammad Bilal H S, et al. (2018). Model-based adaptive user interface based on context and user experience evaluation[J]. Journal on Multimodal User Interfaces 12(1): 1-16. https://doi.org/10.1007/s12193-018-0258-2

Publisher's note Springer Nature remains neutral with regard to jurisdictional claims in published maps and institutional affiliations. 